This is the authors' accepted manuscript of an article published in the International Journal of Cultural Studies, Online First, 1-15, 28th July 2015 which has been published in final form at http://ics.sagepub.com/content/early/2015/07/16/1367877915595302.full.pdf+html

\title{
Introduction: Tricksters, humour and activism
}

\author{
Simon Weaver ${ }^{1}$ \\ Brunel University London, England \\ Raúl Alberto Mora \\ Universidad Pontificia Bolivariana, Colombia
}

\begin{abstract}
This special issue, entitled 'The Trickster Activist in Global Humour and Comedy', investigates the relevance of the concept of the trickster for explaining activist expressions that emanate from comedians, or that appear in comedy and humour more generally. Comedy has traditionally been viewed as an aesthetic or entertainment medium. It has often been charged with encouraging stereotype and the affirmation of mainstream audience beliefs. Despite this, we argue, there have been moments in recent history where comedians have given their performances an increased level of social and political consciousness that resonates with the public at large, or with sections of the public. Comedians, we argue, are able to reach this level of social commentary due to their potential to become tricksters. Paradoxically, the mythical trickster is a liminal entity, one that is adept at destruction as well as creation, or at conservativism as well radicalism. The articles in this issue explore the complexity of the trickster concept, showing some of the polysemy involved in the social activism enabled by comedy and humour.
\end{abstract}

\section{Keywords}

boundary crossing, comedy, humour, liminality, social structure, the trickster

This special issue of the International Journal of Cultural Studies, on the trickster and contemporary comedy, investigates the role of the comedian, comedy and humour as activist or 'active' 'trickster' discourses in contemporary society. Traditionally comedy has been viewed as an aesthetic or entertainment medium, and is also one that has been charged with encouraging stereotype, prejudice and the affirmation of mainstream audience belief (Perez, 2013, 2014; Weaver, 2011). However, there have been examples in recent history where comedians have given their performance an increased level of social and political consciousness that resonates with the public at large, or with sections of that public. Comedians and humorists, the authors in this issue argue, are able to reach this level of social commentary due to the very nature of some of their comic discourse and the potential for it to create or enable 'tricksters'.

Gerald Vizenor's $(1988,1993)$ postmodern discourse on the Native American trickster is an inspirational and motivating force for the discussions in this issue, and is thus drawn on extensively. This is, in part, because Vizenor offers an approach that escapes the mythic reification present in much work on trickster figures (e.g. Tannen,

\section{${ }^{1}$ Corresponding author:}

Simon Weaver, Department of Social Sciences, Media and Communications, College of Business, Arts and Social Sciences, Brunel University London, Uxbridge, UB8 3PH, UK. Email: simon.weaver@brunel.ac.uk 
This is the authors' accepted manuscript of an article published in the International Journal of Cultural Studies, Online First, 1-15, 28th July 2015 which has been published in final form at http://ics.sagepub.com/content/early/2015/07/16/1367877915595302.full.pdf+html

2007), develops the concept of trickster as text or textual practice, and thus aids the applicability of it to contemporary media and cultural examples. For Vizenor, a trickster discourse is 'an uncertain humour that denies aestheticism, translation and imposed representations' (1988: x). Thus, the special issue argues that comedians and humorists are able to open spaces for discussions on many aspects of social structure that can or need to provoke activism, such as gender, sexuality, ethnicity, race, religion, among other issues. These alternative discursive spaces might be considered taboo or could be confined by the limits of hegemonic political or politically correct discourse in other discursive spheres, whereas in comedy, the licence to disrupt or redefine is frequently expanded.

The particular connection between comedic discourse and the trickster, and the possibilities for social activism that past and present comedians in different countries and languages explore, is central to this special issue. The articles in the issue represent discussions from around the globe on how comedians are pushing social discourse to create new limits and intervening on socially relevant topics through their jokes and commentary. The articles approach comedy and humour from multiple disciplines, theoretical perspectives and methodologies. We now sketch some of the central concepts that direct the discussions in the issue and introduce how the articles apply these concepts.

\section{The trickster}

The trickster is a difficult concept to define and the articles in this issue all work towards different definitions that emerge from the comedy and humour examined. In the many trickster myths in anthropology, the trickster appears in creation stories and provides solutions to problems or some explanation for the world being the way that it is. Often these explanations or problems concern paradox. In some accounts, the trickster is a force that seeks to transform, destroy or disturb the existing order (Radin, 1972). The anthropologist Victor Turner (1974) described the trickster as a liminal actor, as someone who appears in unstable situations and has the potential to impact on those situations. The trickster is thus a broker of anti-structure (see below for a more detailed description). Thus trickster discourse is that which can affect the social through unorthodox and possibly subversive means. It is argued that comedy and humour can offer reinterpretations of social order that may disturb that order because of the similarity between liminality and humorous incongruity.

The trickster is a boundary crosser. In offering solutions to problems or explanations and criticisms of the world as it is, the trickster may appear as an outsider, or as one who speaks to the centre from the periphery. Such marginality is a characteristic of many creative figures and much creativity. Thus, the trickster is frequently creative in its mythic incarnation. Bazzil-Morozow explains how 'this means that the trickster has no respect for the structural aspect of the social. Neither does he respect the structuring function of the system' (2015: 15, original emphasis). Comedy is also a discursive practice that crosses some boundaries through the incongruities created in humour, although we would be mistaken in thinking that all comedy is trickster discourse or that all trickster discourse is comical. It is also essential to assert that the boundary crossing of the trickster can be a force for conservativism as well as radical change. A radical system may well fall victim to 
This is the authors' accepted manuscript of an article published in the International Journal of Cultural Studies, Online First, 1-15, 28th July 2015 which has been published in final form at http://ics.sagepub.com/content/early/2015/07/16/1367877915595302.full.pdf+html

conservative tricksters. Some of these complexities are explored in the articles of this special issue.

\section{Humour and comedy}

We have mentioned that humour and comedy lend themselves well to trickster activity. Some forms of humour and comedy have a propensity to disrupt - to deal with both truth and absurdity simultaneously - and thus create the new or disrupt old realities. There are examples of significant trickster discourse that is not the subject of analysis in this special issue. These include the recent emergence of faux news commentators such as Jon Stewart, Stephen Colbert and John Oliver, who have used satire as a way to take the US establishment to task and promote levels of social commentary that much mainstream US media seems unable to engage in. Other comedians have pushed the boundaries of race and racial inequality. Comedy such as Dave Chappelle's 'Racial Draft', Eddie Murphy's mockumentary 'White Like Me' that aired on Saturday Night Live in the 1980s, or the overall oeuvre of the late Richard Pryor provide critiques of white privilege and race stereotypes in contemporary US society. Stand-up comedy has provided further space to raise socially relevant questions and moments of critical consciousness. Comedians such as Bill Hicks, Lenny Bruce, George Carlin, and even Bill Maher, have used comedy to question how US society operates and what people, as a collective, need to do in order to exert real change. This issue steers away from these popular US examples towards less well-known examples from a variety of global locations. Thus, there is an attempt to provide more than a European or North American centred form of analysis and so to cross boundaries that frequently demarcate academic discussion. This, of course, is central to the spirit of trickster discourse, which is often the voice of the outsider or the harbinger of change.

The articles in this issue provide a broad palette, in terms of the genres and styles of humour and comedy discussed, and countries of origin of the material. They all discuss how comedians and humorists push the envelope to discuss 'controversial' topics and social issues through jokes. The articles discuss comedy from multiple disciplines, theoretical perspectives and methodologies. They cover different media, including literary texts, viral videos, internet jokes, stand-up comedy and performance. The articles are international in scope and thus analyse tricksters from different global contexts in recent history. We will now say a little more about how each of the articles in this issue touches on one or another of the key themes of antistructure and boundary crossing.

\section{Creating anti-structure}

The special issue begins with the global phenomenon of Sacha Baron Cohen, whom Joshua Louis Moss describes as performing 'transcomedy', which is exemplary antistructural activity. Moss explores 'the relationship between language, humour and postcolonial affect in the work of Baron Cohen' (this issue), whose four major characters - Ali G, Borat, Brüno and General Aladeen - all employ 'an intentionally unreliable pattern of inter-ethnic word substitutions as a defining characteristic of their performances' (this issue). For Moss:

guttural word-sounds, invented 'foreign' gibberish and fractured English collectively offer a metatextual critique of the power of western spectatorship in contemporary global media. This linguistic fracturing 
This is the authors' accepted manuscript of an article published in the International Journal of Cultural Studies, Online First, 1-15, 28th July 2015 which has been published in final form at http://ics.sagepub.com/content/early/2015/07/16/1367877915595302.full.pdf+html

technique, defined in this article as 'transcomedy', uses the incongruous process of humour to visualize what Homi Bhabha describes as the bifurcated status of the colonized subject' (this issue).

Transcomedy is trickster discourse, and an earlier example of it can be seen in the writing of the critical theorist Gerald Vizenor.

The theme of internal criticism continues with Henry Siling Li's anti-structural discussion of Chinese internet activism. He describes trickster discourse from China in the example of "networked spoof videos, and "narrative dissidence" (Vizenor, 1993: 6) embedded in the construction of an alternative memory in China' (this issue). He reviews the 'relationship between memory and power and the changes that the internet as a mnemonic system has brought to that configuration, before turning to memory policy in contemporary China, and the challenges posed to this policy by active users of the internet' (this issue). Siling Li argues that the control of memory in China is 'realized through the monopoly of the media and the language system' (this issue). He argues that this 'constructive process negates the official version of memory, strips bare all falsities and pretence, and signals an emergent model for the construction of memory and truth in China' (this issue).

From South America, specifically Colombia, Raúl Alberto Mora examines the late Colombian comedian Jaime Garzón - who is another clear example of a comic who attacked the social structure. Mora argues that Garzón was, in many ways, ahead of his time, and presented obvious trickster characteristics. Although Garzón's comedy lifespan barely covered one decade (abruptly halted by his untimely death), his legacy in Colombian comedy and social activism remains strong. Mora describes Garzón as a comedian who was the quintessential Colombian trickster through a framework of what it means to be a trickster in the Latin American and Colombian contexts. The article analyses the social commentary present in Heriberto de la Calle, Garzón's most celebrated character and alter-ego. Through de la Calle, Garzón was able to raise questions about Colombia society, corruption, and confront politicians about daily issues. He became a voice for average Colombians and established a 'new consciousness' of comedy as a tool for social accountability in that society.

Finally, on the theme of anti-structural affect, Danielle Jeanine Deveau investigates 'the Canadian comedian Debra DiGiovanni's self-deprecatory humour as a performative strategy' (this issue) that is trickstereque. Deveau argues that

in keeping with a performance tradition of self-deprecation as established by women comedians such as Phyllis Diller and Joan Rivers, DiGiovanni offers 'failure' as a comic strategy. Her comedy is heavily reliant upon the framing of her lack in terms of relationships, in selfcontrol and in body image (in relation to normative gender standards and expectations). At the same time, however, DiGiovanni also engages critically with gendered expectations of heteronormative desirability, lampooning thin women, superficial men and celebrity culture. Although her comedy is generally characterized by self-deprecation, her humour leaves space for an ambivalent politics of gender. (this issue)

This discussion of gender politics that align with a trickster tradition brings to a close the focus on anti-structure. 
This is the authors' accepted manuscript of an article published in the International Journal of Cultural Studies, Online First, 1-15, 28th July 2015 which has been published in final form at http://ics.sagepub.com/content/early/2015/07/16/1367877915595302.full.pdf+html

\section{Boundary crossing}

The theme of boundary crossing, while emerging in the early articles, is best exemplified in the final three. These all deal with actual or imaginary boundary crossing by a variety of trickster figures. The Moroccan performer, Fatima Chebchoub, is the focus of the next article, by Cleo Jay, who explains that:

North Africa has a long and rich history of theatre using satire as a tool of dissent, although those practices slowly died out during the colonial period. Fatima Chebchoub, a Moroccan academic and theatre maker, was one of the few contemporary directors to use traditional performance practices, and the only trained woman hlayqia, coming from a family of storytellers. Chebchoub was a real pioneer, often performing one-woman shows on sensitive issues such as female sexuality and transgressing social boundaries to take on a variety of personas. At the centre of her large repertoire was comicality: in a country where harsh censorship was still in place. In the tradition of ... the trickster, Chebchoub used performance to engage with society and open dialogues. Both in her professional and private life, she refused to conform and continuously criticized the dominant paradigm, reclaiming a voice for women as well as for impoverished and marginalized parts of Moroccan society. (this issue)

Moving to Central and Eastern Europe, Polina Golovátina-Mora explores Bohumil Hrabal's novel I Served the King of England as a trickster text that reshapes internal, national boundaries. Drawing heavily on both Jungian theory and post-structuralist approaches to language, she argues that 'social activism is inherent to the nature of the trickster figure, namely through the productive and therapeutic power of imagination' (this issue). The article analyses 'the author's style of writing, the novel's composition in the broader context of Czech folklore studies, artistic and literary movements inside the socialist bloc from the 1960s to 1970s, the Jungian archetype, and the Lacanian mirror-stage theories' (this issue). Thus Golovátina-Mora explores how the trickster serves a therapeutic social purpose in Hrabal's novel, which involves enabling an externalization of the problems accompanying the process of individual and collective selfdevelopment' (this issue), Thus, the trickster 'provides for both the author and a reader a shelter for reflection and a possible reconsideration of the self' (this issue). She argues that the trickster character and narrative presents a 'soothing' and, through that, both a warning and advice for society.

Staying in the context of Eastern Europe, in the final article, Simon Weaver and Piotr Ozieranski discuss Polish jokes in the context of European Union (EU) labour migration as a form of trickster discourse that mediates contemporary racism focused on immigration. This is a discussion of the transgression of actual, physical boundaries. They argue that, in the context of contemporary European labour migration, where the most publicized pattern of labour migration sees Eastern European migrants move West, the dominant scholarly interpretation of Polish jokes is not applicable for the analysis of much of the joking by or about the Poles. Humour scholars frequently categorize jokes about ethnic groups into stupid or canny categories, and the Poles have been the butt of stupidity ('Polack') jokes in Europe and the United States. Today, in the EU, Polish stupidity stereotyping in humour is less active and the Polish immigrant is hard working and a threat to indigenous labour, yet joking does not depict this threat in a canny Pole. Weaver and Ozieranski apply the liminal concept of the trickster - an ambiguous border crosser or traveller - 
This is the authors' accepted manuscript of an article published in the International Journal of Cultural Studies, Online First, 1-15, 28th July 2015 which has been published in final form at http://ics.sagepub.com/content/early/2015/07/16/1367877915595302.full.pdf+html

to elaborate some of the characteristics of jokes told by and about Polish migrants in the EU, mainly in the British context.

\section{Conclusion}

We hope that this collection will enliven discussion of the trickster in contemporary humour and comedy studies, and in cultural studies more generally. We hope that it will also contribute to debates on the role of comedy and humour as activist discourses. The global scope of the articles, and the various types, genres and tropes of humour analysed, establish the wide applicability of trickster concepts. Perhaps the central observation, if it is possible to summarize such a thing in a diverse issue like this - is that social structure rarely exists without anti-structure and boundary crossing, and that anti-structure and boundary crossing are essential to the activity of activism, and social life. A look at the different conceptions of the trickster that all six articles portray features some distinct characteristics. Tricksters are provocateurs and dissidents by nature. Throughout history, the different genres where tricksters have appeared always stress the trickster's intent to provoke and raise questions. The articles in this issue particularly explore the questions that trickster discourse can raise. Second, tricksters intend to disrupt the normative, as creators of anti-structure or as boundary crossers. Trickster discourse tends to break with traditional norms and societal codes, opening up new spaces for social activism and critical consciousness. Although not always a liberatory force, the trickster is a precursor of change and disturbance, and closely connected to the recreation of social and cultural life.

\section{Funding}

This research received no specific grant from any funding agency in the public, commercial, or not-for-profit sectors.

\section{References}

Bassil-Morozow H (2015) The Trickster and the System: Identity and Agency in Contemporary Society. London: Routledge.

Pérez R (2013) Learning to make racism funny in the 'colour-blind' era: stand-up comedy students, performance strategies, and the (re)production of racist jokes in public. Discourse \& Society 24(4): 478-503.

Pérez R (2014) Brownface minstrelsy: 'José Jiménez,' the civil rights movement, and the legacy of racist comedy. Ethnicities. Online first, 1 September.

Tannen RS (2007) The Female Trickster: The Mask That Reveals. London: Routledge.

Radin P (1972) The Trickster: A Study in American Indian Mythology. New York: Schocken Books.

Turner V (1974) Liminal to liminoid, in play, flow, and ritual: an essay in comparative symbology. Rice University Studies 60(3): 53-92.

Vizenor G (1988) The Trickster of Liberty: Tribal Heirs to a Wild Baronage. Minneapolis, MN: University of Minnesota Press. 
This is the authors' accepted manuscript of an article published in the International Journal of Cultural Studies, Online First, 1-15, 28th July 2015 which has been published in final form at http://ics.sagepub.com/content/early/2015/07/16/1367877915595302.full.pdf+html

Vizenor G (1993) A postmodern introduction. In: Vizenor G (ed.) Narrative Chance: Postmodern Discourse on Native American Indian Literatures. Albuquerque, NM: University of New Mexico Press, pp. 1-16.

Weaver S (2011) The Rhetoric of Racist Humour: US, UK and Global Race Joking. Farnham: Ashgate.

\section{Author biographies}

Simon Weaver is a Lecturer in Media and Communications in the Department of Social Sciences, Media and Communications, and a member of the Centre for Comedy Studies Research, at Brunel University London, UK. He is a Sociologist who has examined ethnicity, race, racism and humour in his book The Rhetoric of Racist Humour (Ashgate, 2011) and in journals such as Sociology, Current Sociology and Ethnic and Racial Studies.

Raúl Alberto Mora is Associate Professor of English Education and Literacy Studies in the School of Education and Pedagogy Graduate Programs at Universidad Pontificia Bolivariana in Medellín, Colombia. He coordinates the MA in Learning and Teaching Processes in Second Languages and Chairs the Literacies in Second Languages Project (LSLP) at this university. His research explores issues about literacies in today's language ecologies, intersecting areas such as alternative literacies, critical discourse analysis, transmediality and second language education, with a particular interest in the city as a literacy site. 